\title{
The Social Construction of Brown v. Board of Education: Law Reform and the Reconstructive Paradox
}

\author{
Jean Stefancic \\ University of Alabama - School of Law, jstefancic@law.ua.edu \\ Richard Delgado \\ University of Alabama - School of Law, rdelgado@law.ua.edu
}

\section{Recommended Citation}

Jean Stefancic \& Richard Delgado, The Social Construction of Brown v. Board of Education: Law Reform and the Reconstructive Paradox, (2014).

Available at: https://scholarship.law.ua.edu/fac_working_papers/67

This Working Paper is brought to you for free and open access by the Faculty Scholarship at Alabama Law Scholarly Commons. It has been accepted for inclusion in Working Papers by an authorized administrator of Alabama Law Scholarly Commons. 


\section{THE UNIVERSITY OF ALABAMA SCHOOL OF LAW}

The Social Construction of Brown v. Board of Education: Law Reform and the Reconstructive Paradox

Richard Delgado \& Jean Stefancic

36 WILLIAM \& MARY LAW REVIEW 547 (1995)

This paper can be downloaded without charge from the Social Science Research Network Electronic Paper Collection: http://ssrn.com/abstract=2411635 


\title{
THE SOCIAL CONSTRUCTION OF BROWN v. BOARD OF EDUCATION LAW REFORM AND THE RECONSTRUCTIVE PARADOX
}

\author{
RICHARD DELGADO* \\ JEAN STEFANCIC**
}

\section{INTRODUCTION}

Broadly speakıng, there are two vews about Brown v. Board of Education. The conventional view holds that Brown is one of the two or three most important cases in American legal history According to this interpretation, Brown supplied the impetus for the modern clvil rights movement, demonstrated that courts, at least at times, can assert moral leadership, and emphasized that African Americans are entitled to live in the United States on terms equal to whites. ${ }^{2}$

The other new, that of the revisionists, holds that Brown $v$. Board of Education accomplished relatively little, either in the short or long run. ${ }^{3}$ Revisionists argue that Brown is the product of a momentary convergence between white and black interests that began to fade soon thereafter. ${ }^{4}$ Some argue that landmark cases like Brown may even imparr the cause of black nghts by inducing a mood of unwarranted euphoria among supporters

* Charles Inglis Thomson Professor of Law, University of Colorado. J.D., Boalt Hall School of Law, Unversity of Califorma, Berkeley, 1974.

** Research Associate, Unuversity of Colorado School of Law. M.A., Unuversity of San Francisco, 1989.

1. 347 U.S. 483 (1954).

2. Books in this general vein include RICHARD KLUGER, Simple JUSTICE (1976); and JUAN WILLIAMS, EYES ON THE PRIZE (1987). For a discussion of the conventional view and its alleged weaknesses, see Michael J. Klarman, Brown; Racıal Change and the Civil Rights Movement, 80 VA. L. REV. 7 (1994).

3. On the revisionist view of Brown, see, for example, Klarman, supra note 2; on the revisionist view of law reform generally, see GERALD N. ROSENBERG, THE HOLLOW HOPE: CAN COURTS BRING ABOUT SOCIAL ChANGE? (1991); see also Derrick A. Bell, Jr., Brown v. Board of Education and the Interest-Convergence Dilemma, 93 HARV. L. REV. 518 (1980).

4. E.g., Bell, supra note 3. 
while stıffening resistance on the part of diehards and white supremacists. ${ }^{5}$ Revisionists and conventionalists are apt to differ not only in their understanding of Brown, but in their interpretation of how social change occurs. In general, revisionists hold that social reform is difficult to achieve, especially through law, and that gains have a way of slipping back. ${ }^{6}$ The more sanguine conventionalists argue that if Brown has not brought about racial justice by itself, we can at least move closer to this goal through further effort. Brown has certainly helped; and if it has fallen short, what we need is a Brown III or a Brown IV $^{7}$

Although these and other differences separate the revisionists and the conventionalists, in one respect they both approach Brown in the same manner. Each examines the situation that prevailed before and after Brown and asks: Did the landmark decision make a difference? Were the forces that led to the 1960s-era reforms already in motion before Brown? Did Brown benefit white elites more than it benefited blacks? If it benefited blacks, did it help mostly middle-class blacks, leaving the underclass as badly off as before? Both groups, in short, examine Brown longitudinally and temporally, looking for evidence of causation or its lack. The argument has what we might call a vertical character: One lines up the situation that prevailed before Brown, and that after, and looks for signs that Brown brought about changes.

In this Essay, we argue that an ignored, and equally vital, axis is horizontal. 8 To understand Brown's role, and that of law reform cases generally, one must attend to contemporaneous events in society at the time Brown was decided. Focusing on this other dimension enables us to understand why Brown $v$. Board of Education was seen as a breakthrough case, even though it failed to have much effect outside the narrow area of

5. See Derrick Bell, ANd We ARe Not SAVEd: The Elusive Quest For Racial JUSTICE 3, 111 (1987); Klarman, supra note 2, at 85 (discussing the way Brown inspired a wave of southern resistance).

6. See, e.g., Bell, supra note 5; RICHARD Delgado \& Jean Stefancic, Failed REVOLUTIONS: SOCIAL REFORM AND THE LIMITS OF LEGAL IMAGINATION (1994).

7. See, e.g., WILlIAMS, supra note 2.

8. That is to say, an axis that exammes events contemporaneous with a key event, rather than ones that came earlier or later. 
school desegregation. ${ }^{9}$ It enables us to understand why even in that area, Brown had less effect than one might have hoped. ${ }^{10}$ Moreover, focusing on this horizontal dimension allows us to understand law's limitations in propelling social change in general.

We begin by summarizing what Brown was and was not able to accomplish, doctrinally and conceptually, employing as our principal illustration the debate over campus hate speech rules. ${ }^{11}$ We argue that society's resistance to reform in this area is just one example of a backward drift in matters of race, and the decisions whose narratives more aptly characterize our time are not Brown but the nineteenth century Supreme Court cases-Plessy v. Ferguson, ${ }^{12}$ the Civil Rights Cases, ${ }^{13}$ and Dred Scott $v$. Sandford. ${ }^{14}$ Finally, we put forward a reconstructive paradox that names and explains why, despite evidence to the contrary, we contunue to believe the legal system can brang about significant change in areas such as race when it is in fact capable of bringing about very little. ${ }^{15}$

\section{HOW BROWN FAILED TO GENERALIZE}

Many critics have pointed out that Brown accomplished relatively little in the way of school desegregation, except in the Deep South, and that black children are as likely today as they were forty years ago to attend predominantly black schools. ${ }^{16}$

9. See infra notes $16-44$ and accompanyng text.

10. See infra notes 16-24 and accompanying text.

11. See infra notes 30-44 and accompanying text. For writing on the issue of hate speech, see, for example, MARI MATSUDA ET AL., WORDS THAT WOUND (1993); Nadine Strossen, Regulating Ractst Speech on Campus: A Modest Proposal, 1990 DUKE L.J. 484.

12. 163 U.S. 537 (1896).

13. 109 U.S. 3 (1883).

14. 60 U.S. 393 (1856).

15. For an earlier treatment of a related mechanism, the empathic fallacy, see Richard Delgado \& Jean Stefancic, Images of the Outsider in American Law and Culture: Can Free Expression Remedy Systemic Social Ills?, 77 CORNELL L. REV. 1258 (1992).

16. See, e.g., Klarman, supra note 2, at 11-12, 76-86; see also ANDREW HACKER, TWO NATIONS: BLACK AND WHTTE, SEPARATE, HOSTILE, UNEQUAL (1992); THE WORDS OF MARTIN LUTHER KING, JR. (Coretta S. King ed., 1987) [herennafter MLK]; Jerome M. Culp, Jr., Water Buffalo and Diversity: Naming Names and Reclaiming the Ractal 
To this, one could add doctrinal retrenchment in closely related areas. Although subsequent courts have left Brown standing, in the sense that they did not expressly overrule it, they have done much to cut back its effect. School districts may not enact metropolitan desegregation plans, at least in the absence of a showing of prior discrimination. ${ }^{17}$ Education is not a fundamental interest, ${ }^{18}$ nor poverty a suspect class. ${ }^{19}$ States have no obligation to fund property-rich and property-poor districts similarly ${ }^{20}$ Segregation that results from white flight is essentially irremediable. ${ }^{21}$ Black male academies are unconstitutional, ${ }^{22}$ munority scholarships under fire, ${ }^{23}$ and affirmative action that takes the form of reserving slots in state-funded professional schools is illegal. ${ }^{24}$

Why did Brown end up having so little effect, even in the area of school reform? Elsewhere, we have put forward the thesis that social reform through law is relatively ineffective because law's scope is so narrow ${ }^{25}$ Because every social practice is part of an interlocking system of other practices, meanings, and interpretatrons, changing just one element (for example, school assignment rules) leaves the rest unchanged. ${ }^{26}$ Thus, when the Supreme

Discourse, 26 CONN. L. REV. 209, 246-47 (1993) (discussing the situation in law schools).

17. See, e.g., Milliken v. Bradley, 433 U.S. 267 (1977).

18. San Antonıo Indep. Sch. Dist. v. Rodriguez, 411 U.S. 1 (1973).

19. James v. Valtierra, 402 U.S. 137 (1971).

20. Rodriguez, 411 U.S. 1; see also Valtierra, 402 U.S. 137 (upholding state constitutional provision requiring low-rent housing projects to be approved by a majority of qualified electors).

21. Metropolitan desegregation plans are permissible only if the segregation results from official action, not the aggregate of individual decisions by white families to move to the suburbs. See Milliken, 433 U.S. 267.

22. On the difficulties of establishing such schools with public funds, see Jacqueline Concratore, Detroit Must Admit Girls to Public All-Male Academes, Judge Says, BLACK ISSUES IN HIGHER EDUC., Aug. 29, 1991, at 8; Whites in Detroit Teach Students at Black School a Fourth R: Racısm, N.Y. TIMES, Dec. 2, 1992, at B6.

23. See, e.g., Michael A. Olivas, Federal Law and Scholarship Policy: An Essay on the Office for Civil Rights, Title VI and Racial Restrictions, 18 J.C. \& U.L. 21 (1991) (articulating the position of the recent Republican admunistration on this issue).

24. Regents of the Univ. of Cal. v. Bakke, 438 U.S. 265 (1978).

25. See Delgado \& STEFANCIC, supra note 6; see also MLK, supra note 16.

26. E.g., Delgado \& STEFancic, supra note 6; Delgado \& Stefancic, supra note 15. 
Court decided Brown, its principle was soon robbed of much effect when, in a myriad of decisions, school officials, lower courts, sheriffs, and others interpreted Brown against the famil1ar background. ${ }^{27}$ "Of course, the Supreme Court didn't mean that," they would reason in close cases. It is as though legal decisions take place against a gravitational field, with the pull being toward the familiar, toward stasis. ${ }^{28}$ Because Brown set out to change just one element, leaving the force-field itself intact, its effect quickly eroded. For social reform to happen, "everything must change at once," but in the law, doctrines such as stare decisis, standing, mootness, mpeness, and political question mean that the law cannot change everything at once. ${ }^{29}$ It can only decide the case before it.

Disbelieving or obstructionist officials are not the only forces that act to rob landmark decisions of much of their effect. If that were true, all that would be necessary would be vigilance and determined enforcement. Rather, such decisions fail to establish themselves in the wider legal culture, so that even those who are generally sympathetic to reform fail to see their applications in closely related areas.

Consider, for example, the debate over campus hate-speech rules. ${ }^{30}$ Beginning about a decade ago, college and university administrators began noticing an upsurge in the number of racist insults, graffit, and namecalling taking place on their campuses. $^{31}$ At some institutions, the number of students of color began to drop as parents decided to send their sons and daughters elsewhere. ${ }^{32}$ Many campuses responded by enacting

27. See infra notes 51-55 and accompanyng text.

28. See BELL, supra note 5 , at 3 (discussing the way racial breakthroughs erode soon thereafter); see also Richard Delgado, Derrck Bell and the Ideology of Racial Reform: Will We Ever Be Saved?, 97 YALE L.J. 923 (1988) (elaborating on this process); MLK, supra note 16, at 118-19 (on resistance to crvil rights decrees).

29. On these doctnnes and the way they limit the range of cases and issues courts may consider, see RONALD D. ROTUNDA, MODERN CONSTITUTIONAL LAW 102673 (3d ed. 1989).

30. On the problem of hate speech in general, see sources cited supra note 11; on campus hate speech, see Richard Delgado, Campus Antiracism Rules: Constitutional Narratives in Collision, 85 Nw. U. L. REV. 343 (1991).

31. Id. at $348-58$.

32. Id. at 376,386 n.354. 
ant1-hate-speech rules that punished certain forms of racial or sexual taunting or namecalling. ${ }^{33}$ The rules sparked immediate resistance.

Brown at least had some effect. Today, a school official who might be tempted to assign all the black children to one school and the white ones to another, would likely think, "I had better not do that, at least unless I disgurse what I am doing." Today's opponents of hate-speech rules, however, show little such hesitation; they proceed as though Brown had not taken place at all. $^{34}$ Hate-speech rules are in many respects like student-assignment rules. ${ }^{35}$ Yet, opponents make the same arguments against them, the same rhetorncal moves, that we witnessed with the classic resistance to school desegregation.

Under Plessy $v$. Ferguson, ${ }^{36}$ schemes that allocated benefits along racial lines were upheld, so long as the benefit blacks recelved was roughly comparable to that recelved by whites. In Plessy, blacks were forced to ride in one railroad car, whites in another. ${ }^{37}$ The Supreme Court upheld the railroad's rule: separate but equal. Whites and blacks were equally disadvantaged: neither could mde in the other's car. A similar situation prevailed in the schools of Topeka, Kansas, at the time Brown was decided. Indeed, shortly after the decision was announced, a famous constitutional scholar was prompted to wonder if the decision was principled: Why should the rights of blacks to assocrate with whites trump that of whites not to associate with blacks? ${ }^{38}$ One right balanced another, one claim against its perfect reciprocal.

In the debate about hate-speech, we find a strikıngly similar

33. For a discussion of some campuses where rules have been enacted, see $\imath$. at 358-61.

34. See infra notes $40-43$ and accompanying text.

35. For a discussion of these parallels, see Charles R. Lawrence III, If He Hollers Let Him Go: Regulating Racist Speech on Campus, 1990 DuKE L.J. 431; Richard Delgado \& Jean Stefancic, Overcoming Legal Barrters to Regulating Hate Speech on Campuses, ChroN. Higher EDUC., Aug. 11, 1993, at B1; infra notes 38-44 and accompanying text.

36. 163 U.S. 537 (1896).

37. Id. at 537-39.

38. Herbert Wechsler, Toward Neutral Princtples of Constitutional Law, 73 HARv. L. REV. 1 (1959). 
structure. The white insists on a right to say whatever is on his mind. The black demands protection when what is on the white's mund is a direct face-to-face racial insult. One claims a right to do $X$, the other the nght not to have $X$ done to him. One right emanates from one part of the Constitution-the First Amendment-one, from another-the Fourteenth Amendment. ${ }^{39}$ As with separate but equal, today's debate over hate speech features commentators insisting that the black's injury is all in his head. ${ }^{40}$ This perspective parallels early cases in which the Supreme Court told Negroes that the indignity of being herded into separate railroad cars is offensive only if they put that construction on it. ${ }^{41}$ Today's opponents of hate-speech rules dismiss the black's injury as merely dignitary, and not a real harm. ${ }^{42}$ One well-regarded constitutional scholar recently rejected the "silencing" argument by pointing out that it requires mental mediation-the victim decides to remain silent. ${ }^{43}$ As with Brown, the opposition to hate-speech rules portrays itself as highly principled. It is not in favor of hate-speech (heaven forbid). Rather, there are other, higher principles at stake here. ${ }^{44}$

\section{WHY BROWN FAILED TO GENERALIZE}

Brown effected little change in terms of doctrine, consciousness, or the realities of life for black schoolchildren. Yet, society has constructed the decision as a breakthrough of momentous proportions. We believe the two observations are related. Brown's sharp departure from the past caused it to stand out, to seem a breathtaking advance. This departure also assured that

39. For a discussion of these and other sumilarities, see Delgado, supra note 30 , at 345-48; Lawrence, supra note 35 , at $438-40$.

40. See Dinesh D'Souza, Illiberal Edúcation: The Politics of Race and Sex ON CAMPUS 132-36, 156 (1991); NAT HENTOFF, FREE SPEECH FOR ME BUT NOT FOR THEE (1992) (stating that minorities are ready to complain of magined or exaggerated slights).

41. See Plessy v. Ferguson, 163 U.S. 537, 551 (1896).

42. See, e.g., Strossen, supra note 11, at 498 (characterizing the injury to minorlties as merely suffering an unpleasant environment).

43. Cass R. Sunstein, Words, Conduct, Caste, 60 U. CHI. L. REv. 795 (1993).

44. Strossen, supra note 11 (observing that debate implicates our grand national commitment to free speech, academic freedom, the true interests of minorities, and other high-sounding values). 
it would fail to "take"-would succumb to what we called earlier a kund of social gravity ${ }^{45}$ In this Part, we spell out in greater detail what that gravity is. We conclude by describing a "reconstructive paradox" that affects all reform movements, especially those that rely heavily on law and litgation.

\section{A. The Forces That Swallow Socıal Reform Decısions Like Brown}

What we have described as a kind of social gravity that affects all novel social clarms, especially legal ones, has at least three components. As we previously mentioned, it includes the system of meanings and interpretations against which the new rule must operate. ${ }^{46}$ It also includes a set of narratives, or "stock stories," with which the new ruling is required to harmonize. ${ }^{47}$ Lastly, it includes a set of social practices with which the new command must contend. ${ }^{48}$ Each of these components mitigates the new decision's effect. Each is an aspect of what we called the horizontal dimension ${ }^{49}$ of a case, that which was takang place in society at the time the case was adjudicated.

\section{Meanings and Social Interpretations.}

Any text, including legal ones, is interpreted against a background of meanings, presumptions, and preexisting understandings. ${ }^{50}$ If a parent tells a child, "Clean up your room," the terms "clean" and "room" have relatively well agreed-upon meanings: The child knows he or she is not expected to launder the drapes

45. See supra note 28 and accompanying text.

46. See supra notes $28-29$ and accompanying text.

47. See Delgado \& Stefancic, supra note 15; Gerald Lopez, Lay Lawyering, 32 UCLA L. REV. 1 (1984) (discussing the role of narratives and stock stories in constructing social reality and gurding what we do and do not see).

48. See, e.g., Girardeau Spann, Pure Politics, 88 MICH. L. REv. 1971 (1990) (discussing the role of social practices in confining the effect of legal decrees).

49. For an explanation of our use of this term, see supra note 8 and accompanying text.

50. These background elements often reflect the operation of social power and tradition. See Stanley Fish, Is THERE A TEXT IN THIS Class?: ThE AUTHORITY OF INTERPRETIVE COMMUNITIES (1980); Richard Delgado, Shadowboxing: An Essay on Power, 77 CORNELL L. REV. 813 (1992). 
or vacuum the attic space above the room. If an adolescent tells the parent, "I'll be back by midnight," both understand that "midnight" means tonight, not next week, and that "back" means inside the house. The same is true of legal commands. Thus, when Brown ordered school districts to desegregate "with all deliberate speed,"51 southern officials interpreted the decree in terms of their common sense. In hundreds of close cases, they construed Brown to mean the only thing it could mean, consistent with their experience: integration that went not too far, not too fast, and that left the school system as intact as possible. ${ }^{52}$

Operators of public beaches, restaurants, colleges, and other facilities interpreted Brown as a case affecting only schools. Some school officials even took the position that it bound only the districts before the court. ${ }^{53}$ To recalcitrant officials, Brown looked like an exception, an improbable edict that should naturally be interpreted in that light. The only way to harmonize it with common sense was to construe it narrowly" "Of course, the Supreme Court did not mean that blacks and whites are strictly equal," they told themselves. "They surely didn't mean that we would have to do this" (assign black principals to white schools; provide college counseling to all; adopt due process protections in school discipline cases affecting black children facing expulsion, and so on). Because Brown was interpreted against the background of a myriad of such understandings, traditions, and expectations, and because, unlike a parent, the Supreme Court was not instantly available to clarify what it meant, the case had relatively little impact. It did change one thing, pupil assignment rules, but the rest of society remained essentially the same. ${ }^{54}$ The gain in this one area was quickly swallowed up by interpretive effects emanating from all the others. ${ }^{55}$

51. Brown v. Board of Educ., 349 U.S. 294, 300 (1955) (Brown II).

52. See, e.g., DERRICK A. BELL, JR., RACE, RACISM AND AMERICAN LAW 552-54, 565-607 (3d ed. 1992) (discussing the process of interpretation); Klarman, supra note 2 , at $12,76-85$.

53. BELL, supra note 52 , at 118-20, 565-607.

54. See supra notes 17-26 and accompanying text; infra notes 78-81, 84-92 and accompanying text.

55. BELL, supra note 52; see also sources cited supra note 3 (discussing revisionist Interpretations of Brown). 


\section{Socıal Practıces.}

A second component of what we have called the gravitational field against which new legal rules must operate is the set of preexisting social practices, most of which the Supreme Court is powerless to change. These include friendship patterns, the way a teacher looks at or responds to a black child, and that child's own self-concept and expectations with respect to treatment from whites. These practices include the ways in which librarians, bus drivers, shop owners, and landlords deal with the young black schoolchild and his or her family They include who is chosen for student body president, the debate team, and the cheerleading squad. If all of these practices remain the same while only school assignment rules change, a black child's life will not be greatly improved after Brown (and may be considerably worse). ${ }^{56}$

Of course, a forced change in one social practice theoretically could prompt reconsideration of all the others. Because white schoolchildren now are required to attend school in a building that will house some blacks, the other social practices we have mentioned might begin to change. But everything we know about cognitive dissonance and resistance to the unfamiliar suggests the opposite. ${ }^{57} \mathrm{New}$ practices that are discordant with old ones are resisted and adopted, if at all, slowly and grudgingly ${ }^{58} \mathrm{New}$ reasons are found to justify now disputed social practices. 59

\section{The Role of Narratives.}

A final component of the social milieu that affects the reception of a legal decision or rule is the backdrop of narratives or stomes against which the new element will be forced to operate. ${ }^{60}$ Narratives are the simple, script-like interpretive struc-

56. See MLK, supra note 16, at 6 (observing that the costs of racial remedies generally are exacted from blacks); Spann, supra note 48 .

57. See Leon Festinger, A Theory of Cognitive Dissonance (1962).

58. Id.

59. Id.

60. See, e.g., Delgado \& Stefancic, supra note 15 (discussing the role of narratives In shapıng how we see the world); Delgado, supra note 30. 
tures-"he hit first," "I didn't know it was yours," "majority rules," or "I've been here longer"-that we use in ordering our understanding of the world. ${ }^{61}$

In the school desegregation setting, court decrees confront a whole host of narratives and social perceptions that generate resistance. Such narratives include: "Neighborhood schools are best"; "who are these outsiders tryng to tell us what to do?"; "our Negroes were happy until "; "black people just want to push into where they are not wanted"; "they want things they don't deserve and haven't earned"; "integration might be okay, but the schools should remain predominantly white, and the curriculum, teachers, and so on, roughly as they are now"; etc. ${ }^{62}$

As with meanings and social practices, these and other narratives could theoretically change. A person who holds a stock of hundreds of such narratives regarding munority people, neighborhood schools, and "the way things are" could radically revise his or her worldview when confronted by the image of a surprisingly nice, intelligent, reasonable black individual at a school or work place. But narratives change very slowly, in part because we interpret new experiences and new narratives in terms of the old ones-the ones we hold. ${ }^{63}$ These old narratives, indeed, form the basis for understanding new experiences, including that of our first close black associate. It is far easier to pronounce the black an "exception" than to revise one's entire stock of beliefs.

Eventually, of course, social stories and practices change. But they do much more slowly than we like to think. ${ }^{64}$ And when they do, courts and decrees play little role in bringing about the change. ${ }^{65}$ Courts are usually distant institutions. Unlike fleshand-blood persons, they cannot follow up an exchange by sayng, for example: "No, he is not an exception; most of them are like that if you take the trouble to get to know them." Courts are not

61. See, e.g., Delgado \& Stefancic, supra note 15.

62. See Klarman, supra note 2 (discussing this resistance).

63. See Delgado \& Stefancic, supra note 15, at 1259-60 (defining "empathic fallacy" as the belief that we can change our own, and each other's, belief systems quickly and easily by presenting new arguments, stories, or accounts).

64. Id.

65. See Rosenberg, supra note 3; Delgado \& Stefancic, supra note 6. 
in a position to engage society in the knd of continuing dialogue that could in theory change meanings and practices. ${ }^{66}$ They can only change one practice at a time. Everything else-the entire system of practices, traditions, and meanings-remains the same, exerting its gravitational tug toward the familiar. In giving obedience to the new decree-something the courts are in a position to enforce-hundreds of lower-level bureaucrats, state officials, and lower court judges will interpret the ringing words according to their common sense understandings about persons, about relations, and about what is just and deserved. ${ }^{67}$

\section{B. The Reconstructive Paradox}

The combined effect of the forces just mentioned means that any reform measure other than the smallest and most incremental will meet predictable resistance, reinterpretation, and obstruction in ways that the legal system is ill equipped to manage and counter. ${ }^{68}$ One perspective from which to view these horlzontal forces is in terms of what we call the "reconstructive paradox." After defining the paradox, ${ }^{69}$ we illustrate its operation by demonstrating that the current approach to race and race remedies shows the influence of the nuneteenth-century cases, especially Plessy $v$. Ferguson, more than that of their more famous twentieth-century rival, Brown v. Board of Education. ${ }^{70}$

\section{Defining the Reconstructive Paradox}

Much of what we have sand so far can be summarized in the following six steps, constituting what we call the reconstructive

66. Communities (large collectivities) by contrast, are essential to the process of forming and sharıng meanings. See, e.g., Frank I. Michelman, Foreword: Traces of Self-Government, 100 HARV. L. REV. 4 (1986); see also FISH, supra note 50, at 278-81 (illustrating one court's limited ability to communicate the meaning of statutory language). Federal judges are situated too distantly and remotely to effect rapid change in social meanings.

67. See supra notes $27-29,50-53$ and accompanyng text.

68. See Delgado \& Stefancic, supra note 15, at 1258-59 (observing that speech and dialogue can effectively correct small, clearly bounded, but not systemic, error).

69. See infra text accompanying notes 71-77.

70. See infra text accompanying notes 78-130. 
paradox:

(1) The greater a social evil (for example black subordination) the more it is apt to be entrenched in our national life. ${ }^{71}$

(2) The more entrenched the evil, the more massive the social effort that will be necessary to eradicate it. ${ }^{72}$

(3) The harm of an entrenched evil will be invisible to many because it is embedded and ordinary ${ }^{73}$

(4) The massive social effort will unevitably collide with other social values and things we hold dear (for example, settled expectations, religion, the family, privacy, the southern way of life, etc.). It will entail dislocations, shifts in spending priorities, new taxes, and changes in the way we speak and relate to each other. $^{74}$

(5) These efforts, by contrast, will be highly visible and will spark resistance and accusations that the backers are engaging in totalitarian tactics, siding with big government, dislodging innocent whites, operating in derogation of the merit principle, elevating group over individual relief, reviving old grudges, whipping up division where none existed before, and so on. ${ }^{75}$

(6) Resisting these latter complaints will feel right and proper, for the other side will appear to be callously sacrificing real liberty, real security, and real resources for a nebulous goal. ${ }^{76}$

Therefore, reconstruction will always strike many in a society as unprincipled, unwarranted, and wrong. Little surprise, then, that few take up its cause, persist for long in the face of the resistance it calls forth, or even frame their programs and objec-

71. See, e.g., Delgado, supra note 50; Delgado \& Stefancic, supra note 15.

72. Racism, for example, is generally agreed to consist of a complex of attitudes and practices that permeate institutions and individuals. See, e.g., THE Sociology of Race Relations: Reflection AND Reform (Thomas F Pettigrew ed., 1980); Charles R. Lawrence III, The Id, The Ego, and Equal Protection: Reckoning with Unconscious Ractsm, 39 STAN. L. REV. 317 (1987) (reconsiderng the doctrine of discriminatory purpose).

73. See Derrick Bell, Racral Realism, 24 ConN. L. REv. 363 (1992) (suggesting that racial equality is unobtanable because of the entrenched racism of Americans).

74. Id., see also BELL, supra note 5 (doubting that society will ever undertake such an effort).

75. Bell, supra note 73; Richard Delgado, Rodrigo's Chronıcle, 101 YALE L.J. 1357 (1992).

76. Richard Delgado \& Jean Stefancic, Imposition, 35 WM. \& MARY L. REV. 1025 (1994). 
tives broadly enough so that if they are adopted, they have a chance of remaining in place and achreving some real effects.

2. Back to Plessy Present-Day Rhetoric and Evidence of the Reconstructive Paradox Operating in Our Time

Reform through law alone, as we mentioned, is apt to have little effect, because legal decrees succumb silently and painlessly to interpretation and other forms of cultural weight. ${ }^{77}$ Even when, as happened with the c1vil rights revolution of the 1960s, legal reform operates in concert with broader social forces to produce undeniable and much-needed gains, resistance is apt to set in at some point. Consider how today we no longer talk in terms of separateness as an inherent injury, of black schoolchildren as victims, or of racism as a harm whose injury "is unlikely ever to be undone." Instead, we speak of the need for formal neutrality, of the dangers affirmative action poses for innocent whites, and of the need for black Amencans to look to their own resources. ${ }^{78}$ Moderates and conservatives alike have rolled back affirmative action ${ }^{79}$ and challenged university and college theme houses, special curricula, and ethnic studies departments, ${ }^{80}$ which they see as violations of the merit principle and fair and equal treatment policies. Courts are qunck to strike down set-aside programs and affirmative action plans as "quota systems" likely to discrimmate against "innocent whites." narrative of Plessy $v$. Ferguson ${ }^{82}$ more aptly characternzes our

77. See supra notes 50-67 and accompanying text.

78. Delgado \& Stefancic, supra note 76 (collecting and evaluating examples of judicial and social rhetoric regarding blacks and other minorities); Thomas Ross, Innocence and Affirmative Action, 43 VAND. L. REV. 297 (1990).

79. See, e.g., Regents of the Univ. of Calif. v. Bakke, 438 U.S. 265 (1978) (holding that admissions program which reserved positions in medical school class for disadvantaged munority students was unconstitutional). For a discussion of this retrenchment, see JOEL DREYFuSS \& CHaRLES LAWRENCE III, THE BAKKE CASE: THE POLITICS OF INEQUALITY (1979).

80. See, e.g., D'SouZA, supra note 40 (discussing the academic and cultural revolution at American universities).

81. See, e.g., City of Richmond v. J.A. Croson Co., 488 U.S. 469 (1989) (strikıng down plan requirng city construction contracts to subcontract $30 \%$ of each contract to minority-owned busınesses); Thomas Ross, The Richmond Narratives, 68 TEx. L. REV. 381 (1989).

82. 163 U.S. 537 (1896). 
attitudes with respect to race than do the stirmng words of Brown.

In Plessy, United States Supreme Court Justice Brown could not see anything wrong with a system that required blacks to sit in separate railroad cars, overlooking the unmistakable damage inflicted on blacks' sense of dignity by such a discrmminatory system. Indeed, he wrote:

We consider the underlynng fallacy of the plaintiffs argument to consist in the assumption that the enforced separation of the two races stamps the colored race with a badge of infernority If this be so, it is not by reason of anything found in the act, but solely because the colored race chooses to put that construction upon it. ${ }^{83}$

In a recent case, City of Memphis v. Greene, ${ }^{84}$ Justice Stevens declared that a municipal decision to separate a white neighborhood from a black one by allowing the construction of a wall between them to regulate traffic flow was fair and not motivated by an intention to discriminate against blacks, but rather by an "interest in protecting the safety and tranquillity of a residential neighborhood." ${ }^{85}$ Echoing the earlier opinion of Justice Brown in Plessy, Stevens wrote:

Because urban neighborhoods are so frequently characterized by a common ethnic or racial heritage, a regulation's adverse impact on a particular neighborhood will often have a disparate effect on an identifiable ethnic or racial group. To regard an inevitable consequence of that kind as a form of stigma so severe as to violate the Thirteenth Amendment would trivialize the great purpose of that charter of freedom. $^{86}$

In both cases, separated by nearly a century, during which much progress in race relations was sard to have been made, blacks have been presented with a rhetorical legerdemain that tests both their ability to participate in societal self-deception and their inclination to prevail in the face of it.

83. Id. at 551.

84. 451 U.S. 100 (1981).

85. Id. at $119-20$.

86. Id. at 128. 
Other modern-era cases show the same tendency to disregard blacks' long-standing predicament or whites' contribution to it. Because Brown only addressed the effects of segregated educatron on black schoolchildren, remaining silent on the issue of white responsibility, it was perhaps inevitable that the question of fault would become the next hurdle to blacks struggling to achieve social gains. Washington $v$. Davis ${ }^{87}$ is perhaps the most well-known example, but there have been a number of others. In Arlington Heights v. Metropolitan Housing Development Corp. ${ }^{88}$ the Court held that certain zoning regulations that had the effect of excluding blacks were constitutionally valid because they were not enacted with that purpose in mind. ${ }^{89}$ In San $A n$ tonio Independent School District v. Rodriguez, ${ }^{90}$ a school finance scheme that caused a great disparity in funding tax-rich and tax-poor schools was upheld despite its serious impact on poor and minority children. ${ }^{91}$ And, as mentioned earlier, a traffic control measure that took the form of a wall between white and black neighbors in Memphis was deemed just that, a traffic control measure, despite the way in which it physically and symbolically separated the races. ${ }^{92}$

Each of these cases foreshadows a retreat from the runging words of Brown; each in many ways is reminiscent of the crabbed neutrality and unrealistic refusal to see discrimmation that characternzed Plessy Not only has our time implicitly resurrected Plessy in its approach to racial justice, but a second notomous nineteenth century case's star is rising: the Civil Rights Cases. ${ }^{93}$ In the Civil Rights Cases, the Supreme Court wrote that blacks who were demanding equal access to vanous types of public accommodation were seriously overstepping and in effect demanding to be afforded special treatment. The Court wrote:

87. 426 U.S. 229 (1976) (holding that a test adminıstered to black applicants for employment as police officers was not unconstitutional because the purpose was not discriminatory even though the impact may have been).

88. 429 U.S. 252 (1977).

89. Id. at $268-70$.

90. 411 U.S. 1 (1973).

91. Id. at 54-55.

92. See supra notes 84-86 and accompanyıng text (discussing City of Memphis v. Greene, 451 U.S. 100 (1981)).

93. 109 U.S. 3 (1883). 
When a man has emerged from slavery, and by the and of beneficent legislation has shaken off the inseparable concomitants of that state, there must be some stage in the progress of his elevation when he takes the rank of a mere citizen, and ceases to be the special favorite of the laws, and when his rights as a citizen, or a man, are to be protected in the ordinary modes by which other men's rights are protected..$^{94}$

Cases in our time show much the same attitude. Blacks' demands for justice are themselves unjust, because they are a form of asking for special treatment and because they encroach on white privilege and settled expectations. One example is Regents of the University of California $v$. Bakke. ${ }^{95}$ There, the Supreme Court upheld the challenge of a white applicant to a state-sponsored medical school. ${ }^{96}$ The plurality opinion cast him in the role of victim. The medical school's affirmative action program, which reserved a small number of slots for African Americans, unconstitutionally volated the rights of applicants such as Bakke. ${ }^{97}$ The Unıversity's program operated unfairly against "innocent persons in respondent's position." The state's interest in remedying past discrimination was not sufficiently compelling to justify the "special treatment" black candidates received. In language reminiscent of Justice Bradley's in the Civil Rights Cases, the plurality opınıon painted the university's affirmative action program to increase the number of black doctors as coddling and favoritism..$^{99}$ Other recent affirmative action cases have taken a similar position and employed rhetoric nearly as unsympathetic as that of Bakke. ${ }^{100}$

The most startling parallel is found in City of Richmond $v$.

94. Id. at $24-25$.

95. 438 U.S. 265 (1978).

96. Id.

97. Id. at 320 .

98. Id. at 298 (plurality opınıon of Powell, J.).

99. Id. at $295,298-99$.

100. E.g., Wygant v. Jackson Bd. of Educ., 476 U.S. 267, 274-76 (1986) (rejecting role-model argument for affirmative action as dangerous, unproven, and potentially unbounded). 
J.A. Croson Co. ${ }^{101}$ where the Court struck down a minority set-aside program in the construction industry that had been adopted by the Richmond city council. ${ }^{102}$ The majority opınıon found the council's action a potential case of "simple racial politics."103 A concurring opınion went even further, warning that society should be watchful aganst those who might attempt to "even the score" at the expense of whites. ${ }^{104}$

Societal rhetoric follows suit. A host of commentators today rail against multicultural programs on university campuses; ${ }^{105}$ minority-only scholarships are under fire; ${ }^{106}$ welfare programs are under sustained attack as disguised give-aways to undeserving, unambitious, and oversexed blacks; and the use of codewords, like "political correctness" indicates that many in our society believe that blacks have gone too far. ${ }^{107}$ They are now receiving special, not just equal treatment. It is time to put a stop to it, just as it is time to begin closing our borders to immlgration from Mexico, Hait,, Cuba, and other societies of color. ${ }^{108}$

We believe, then, that dispassionate examination of today's dominant narratives shows that the themes of Plessy and the Civil Rights Cases are in ascension. We put forward an even more somber prediction: Unless there is concerted action or a sharp change in national circumstances, one final step will be taken. Just as the clock of time seems to be rolling backward, a final narrative may soon regain prominence: that of Dred Scott v. Sandford. ${ }^{109}$

101. 488 U.S. 469 (1989).

102. Id.

103. Id. at 493 .

104. Id. at 527-28 (Scalia J., concurmng).

105. E.g., D'SouZA, supra note 40.

106. See supra note 23 and accompanying text.

107. For examples of various social texts, ranging from editorials to conservative treatises, see Delgado \& Stefancic, supra note 76.

108. Id. at 1032 (discussing Immigration issues); Gerald L. Neuman, Back to Dred Scott, 24 SAN DIEgo L. REV. 485 (1987) (reviewing PETER SHUCK \& ROGER SMITH, Citizenship Without CONSENT: ILlegal AliENS IN THE AMERICAN POLITY (1985)).

109. 60 U.S. 393 (1856). For other discussions of the rhetorical parallels between Dred Scott, other nineteenth century cases, and today's cases, see Ross, supra note 78; Thomas Ross, The Rhetorical Tapestry of Race: White Innocence and Black Abstraction, 32 WM. \& MARY L. REV. 1 (1990). 
In Dred Scott, the Supreme Court, in a case concerning a runaway slave, held that African Americans have "no nghts which the white person is bound to respect." African American to citizenship was absurd, both historically and legally Blacks simply were not citızens because they never were such and the framers of the Constitution, "great men," never regarded them that way ${ }^{111}$ Dred Scott constitutes, certainly, the nadir of American law's treatment of African Amerncans, a blot on the record of the American legal conscience. Yet, its narrative retanns vitality today We see growng evidence of it in Supreme Court opinions and in popular culture. ${ }^{112}$

Justice Taney's opinion depicted blacks as subhumans. ${ }^{113}$ Is this shockung portrayal of other beings so far from today's range of possibilities? Is the story of the primitive bestial black or Mexican completely missing in today's narratives, both in popular culture and in judicial opimions? Unfortunately, we believe not. Indeed, we believe this account of groups of color is undergoing a resurgence.

Consider, for example, the revival of race-IQ theories, some seconded by well-regarded scientists and writers such as Charles Murray, Richard Herrnstein, ${ }^{114}$ Arthur Jensen ${ }^{115}$ and William Shockley ${ }^{116}$ Consider the number of books, such as Ben Wattenberg's The Birth Dearth, ${ }^{117}$ and reports that have urged renewed attention to the question of selective breeding: Our "best" citizens have too few children; minorities and the poor, too many, so that the gene pool in the United States is declining. Consider the resurgence of nativism and movements to close the

110. Id. at 404-07.

111. Id, at 410 .

112. See infra notes $122-128$ and accompanying text.

113. Dred Scott, 60 U.S. at 405-10 (depicting history of blacks as chattels).

114. RICHARD J. HERRNSTEIN, IQ IN THE MERITOCRACY (1973); RICHARD HERRNSTEIN \& CHARLes MuRRAY, THE BELL CURVE (1994).

115. Arthur Jensen, How Much Can We Boost IQ and Scholastic Achlevement? 39 HARV. EDUC. REV. 1 (1969).

116. For a discussion of the Nobel prize-winning scientist's controversial news on race and IQ, see Richard Delgado et al., Can Sctence Be Inopportune? Constitutional Validity of Governmental Restrutions on Race-IQ Research, 31 UCLA L. REV. 128 (1983).

117. Ben J. Wattenberg, The Birth Dearth (1987). 
nation's borders partıcularly to brown-skinned immıgrants. ${ }^{118}$ Consider also the English-Only movement. ${ }^{119}$ Much of this attitude is fueled by the conviction that "those people" are not fit to reside here, that their language, customs, and morals are inferior, and that they are and always will be second-class citizens. All of these cultural strands converge around the idea that this is a white country and that nonwhite persons, genes, ideas, languages, and culture are inferior to European ones, a principal theme in Dred Scott.

Nor has the legal system been totally divorced from the return of the Dred Scott mentality In the Rodney King case, a Los Angeles-area jury acquitted police officers who were videotaped beating a black motorist while he lay unresisting on the ground. ${ }^{120}$ Testimony by the police and later intervews with the jurors showed that the motorist, King, was seen as the kind of being who might resist, who might at any moment strike out with tremendous force, and who, because he was caught speeding, deserved whatever penalty the police chose to inflict. ${ }^{121}$

Supreme Court decisions also contain hints of Dred Scott and its brusque dismissal of African American humanity In McCleskey $v$. Kemp, ${ }^{122}$ the Supreme Court considered a challenge to Georgia's infliction of the death penalty, which fell disproportionately heavily on blacks, particularly ones whose victıms were white. ${ }^{123}$ The Court rejected McClesky's claim, at the same time reprimanding him and his lawyers for even having brought it. ${ }^{124}$ Such claims, based on statistical disparities,

118. E.g., Neuman, supra note 108. On the history of U.S. nativism, see NATIVISM, DisCrImination, AND IMAGES OF IMMigRanTs (George Pozzetta ed., 1991).

119. For a discussion of this and similar language-purification efforts, see Delgado \& Stefancic, supra note 76, at 1035; Juan Perea, Demography and Distrust: An Essay on Amercan Language, Cultural Pluralism, and Official English, 77 MaNN. L. REV. 269 (1992).

120. For a collection of essays on the Rodney King case and the L.A. disturbances that followed, see Symposium, Los Angeles, April 29, 1992 and Beyond: the Law, Issues and Perspectives, 66 S. CAL. L. REV. 1313 (1993).

121. Id., see Jerome M. Culp, Jr., Notes From California: Rodney King and the Race Question, 70 DENV. U. L. REV. 199 (1993).

122. 481 U.S. 279 (1987).

123. Id.

124. Id. at 319 ("McCleskey's arguments are best presented to the legislative bod1es."). 
might be rassed in virtually any setting, the Court reasoned, resulting in repetitive demands "based upon any arbitrary variable."125 Cases brought by poor women-Wyman $v$. James $^{126}$ (the welfare-search case), Maher $v$. Roe, ${ }^{127}$ and other abortion-funding cases-show the same thinly veiled exasperation on the part of the Court. These decisions stop barely short of telling poor women that they do not know their places and what is expected of them-to be as quiet, prudent, nondemanding, and nonsexual as possible. The demand for pmvacy in the face of a welfare inspection, or for an abortion from a state-funded clinic, appears outrageous. The women are chastised for the effrontery of wanting to live life on their own terms. ${ }^{128}$

Many earlier eras, of course, witnessed similar patterns of advance followed by retrenchment. During Reconstruction, African Amencans made great gains, but these were followed by an era of lynching and Jim Crow laws. ${ }^{129}$ Brown $v$. Board of Education was followed by new resistance in the South. ${ }^{130}$ In Europe, the broadened vistas and relaxed worker-migration policies of the early European Community years soon were followed by xenophobia, a resurgence of Nazism, and tightened controls on immigration. ${ }^{131}$ We believe the United States is in the middle of such a retrenchment today Indeed, it is as though the arrow of time has reversed. We see the nineteenth-century cases appearing in modern guise before our eyes-first the Plessy line of cases, then the notonous Civil Rights Cases, and finally, in the wings, Dred Scott $v$. Sandford.

125. Id. at 317 .

126. 400 U.S. 309 (1971).

127. 432 U.S. 464 (1977).

128. Delgado \& Stefancic, supra note 77 , at 1033.

129. BELL, supra note 52, at 39-46; ERIC FONER, RECONSTRUCTION: AMERICA'S UNFINISHED REVOLUTION (1988).

130. E.g., Klarman, supra note 2, at 12-13, 76.

131. E.g., European Parliament Committee of Inquury on Racism and Xenophobia, Report on the Findings of the Inquiry (1991); Commission of the European Communities, Legal Instruments to Combat Rac1sm and Xenophobia (1992); Italians Examine Fascist History, DEN. PosT, Apr. 9, 1994, at 21A. 


\section{WHAT BROWN AND THE RECONSTRUCTIVE PARADOX MEAN FOR ACTIVISTS AND REFORMERS: SUMMARY AND SUGGESTIONS}

Brown, like all law reform cases, confronted built-in resistances that deprived it of the efficacy its supporters hoped for it. Social reform proceeds, if at all, in small increments; the pendulum swing is as apt to be backward at any given time as forward. Brown's relatively slight effect is part of a broader form of social response-the reconstructive paradox-which holds that the greater the evil, the greater the need for reform; the greater the reform effort, the more unprincipled and unjust the effort will seem, and the greater the resistance it will call up. Even more than other avenues for reform, law is handicapped by its inability to engage in dialogue with the group whose values and practices need changing. Except in criminal law, where it can put violators in jail, law has little ability to provide the constant reinforcement necessary to change attitudes or behavior. Indeed, law is always outnumbered; doctrines such as standing ensure that any wide-ranging legal edict appears incomprehensible and wrong, evoking the reaction: Surely the court didn't mean that.

If we are right, reformers should hesitate to place much faith in the legal system as the primary instrument for their agendas. ${ }^{132}$ Law is relatively powerless to effect social revolutions as both theory and history, including the case of Brown, demonstrate. Everything must change at once, so that a far greater focus than the merely legal is necessary before reform begins to be possible. Because the reconstructive paradox has greatest force with respect to courts, reformers ought to reserve judicial activism for the later stages of a revolution, using courts for the final mopping up steps to secure a social advance that society has already begun to accept.

Litigation is expensive and frustrating if resorted to at the wrong time. We urge that reformers reconsider the appropriate time to use it. If employed too early, as it arguably may have

132. Compare our conclusion with similar ones drawn by GIRARDEAU A. SPANN, RACE AGAINST THE COURT (1993) (observing that Supreme Court litigation is of limited use as an instrument of racial reform) and BELL, supra note 5, at 26-50; see also MLK, supra note 16, at 5 (sımilar observation about romantic view of law and law's efficacy). 
been with Brown, it leads to false celebration, then disillusionment by persons who, like African Americans, have waited too long to see their just demands met-then betrayed.

\section{CONCLUSION}

Society has constructed Brown v. Board of Education as a great case. Yet, as we have seen, the opinion failed to generalize and accordingly exercised little influence outside the area of school desegregation. Even within that arena, it brought about relatively few improvements in the lives of black schoolchildren, most of whom today attend schools that are just as segregated and in even greater disarray than the ones they attended in Brown's time.

We believe the two observations are related, indeed dependent on one another. We saw Brown as a startling, extraordinary decision-which it was-for the very reasons that brought about its demise-namely, the way in which it challenged and departed from current culture and orthodoxy Every law-reform dec1sion, we pointed out, takes place against a background of beliefs, narratives, meanings, and social practices that constitute a kind of social gravitational field. This field causes the exceptional case to erode quickly, to be resisted, interpreted away, and increasingly ignored. This dissipation has visited Brown v. Board of Education. Although we afford it lip service and pay attention to its ringing, aspirational message on celebratory occasions, other narratives have turned out to have greater vitality These more lasting narratives are those of the nineteenth century cases, ones that celebrate white supenority, that depıct blacks as inferior, subhuman, demanding, and unjustified. As a culture, and as a legal profession, we are rapidly returning to the regime of Plessy v. Ferguson's separate but equal doctrine and the Civil Rights Cases view of blacks as imposers and whiners because they desire to live in American society on the same terms as whites. Moreover, we find some frightening straws in the wind-indications that ought to give pause to any defender of freedom and minority nghts. We have reviewed evidence that society generally, and the legal system in particular, are beginning to regress in one final, decisive quantum jump. American society, without the spur of Cold War competition or the need for 
minority labor or soldiers, is in sernous danger of quetly, implicitly readopting a familiar standard from another era: Dred Scott $v$. Sandford, in which blacks and other minorities of color have no nghts that white Americans are bound to respect. 